\title{
Pengaruh Informasi Website Perpustakaan Terhadap Sikap Mahasiswa
}

\author{
Studi Pengaruh Informasi Website http://library.binus.ac.id Terhadap \\ Sikap Mahasiswa dalam Memenuhi Kebutuhan Informasi Ilmiah \\ di Universitas Bina Nusantara
}

\author{
Sri Sulastri \\ Perpustakaan Universitas Podomoro
}

\begin{abstract}
Abstrak - Penggunaan internet telah merambah ke segala aspek kehidupan terutama pada bidang pendidikan. Informasi website perpustakaan, perpustakaan Universitas Bina Nusantara merupakan sumber informasi yang dapat dipergunakan oleh mahasiswa dalam memenuhi kebutuhan informasi ilmiahnya.Hal ini ditandai dengan banyaknya akses mahasiswa pada website perpustakaan setiap bulannya. Akses terhadap informasi dalam website dipengaruhi oleh pengetahuan terdahulu mahasiswa dan juga informasi yang mempunyai nilai dan kualitas. Penelitian dilakukan untuk mengetahui besarnya pengaruh informasi website perpustakaan berdasarkan teori integrasi informasi menurut Feishbein dilihat dari aspek valensi atau nilai informasi dan bobot informasi sebagai variable bebas $(X)$ terhadap sikap mahasiswa dalam memenuhi kebutuhan informasi ilmiah dalam hal ini variabel terikat $(Y)$. Selain itu juga untuk mengetahui besarnya pengaruh pengetahuan terdahulu sebagai variabel antisendent (A) terhadap valensi dan bobot informasi. Dalam penelitian ini populasi sebesar 1370 orang, dan untuk penarikan sampel digunakan rumus Yamane dengan tingkat kesalahan 5\%, sehingga diperoleh 310 sampel, penentuan sampel dilakukan dengan cara mengundi Nomor Registrasi Pokok Mahasiswa.Pengujian hipotesis dengan menggunakan analisis jalur dengan terlebih dahulu merubah skala data ordinal menjadi interval melalui teknik Method of Successive Interval.Dari penelitian yang dilakukan diketahui bahwa secara simultan informasi website perpustakaan memiliki pengaruh secara signifikan terhadap sikap mahasiswa dalam memenuhi kebutuhan informasi ilmiah, melalui valensi dan bobot informasi. Berdasarkan hasil analisis jalur, valensi dan bobot informasi berpengaruh baik secara langsung maupun tidak langsung dengan variable bobot informasi yang memiliki paling berpengaruh terhadap sikap mahasiswa.Serta pengetahuan terdahulu memiliki pengaruh yang signifikan terhadap valensi dan bobot informasi.
\end{abstract}

Kata kunci : valensi informasi, nilai informasi, bobot informasi website, teori integrasi informasi
Abstract - The utilization of internet has penetrated into all aspects of life, especially on education. The library's Website information in Bina Nusantara University is a source of information which can be used by students to fullfill the needs of scientific information. It is shown by the number of student's access to the library's website each month. Access to information on the website is influenced by prior knowledge of the students and also the value and quality of the information provided on website. The research was conducted to determine the effect of the library website based information integration theory according to Feishbeinon valence aspects or information value of information and quality of information as a independent variable $(X)$ on the Students Attitudes to fulfill the needs for Scientific Information in this case the dependent variable $(Y)$. Also to determine the influence of prior knowledge as a variable antecedent $(A)$ on the valence and quality of information.The study population is 1371 people and the withdrawal of samples used the Yamane formula with an error rate of $5 \%$, in order to obtain 310 samples, sampling is conducted by raffle of Principal Student Registration Number (NRP). Testing of hypotheses used the path analysis by changing the scale of ordinal data into interval through engineering Method of Successive Intervals. In this research, it is found that simultaneously, information library website has a significant effect on the attitudes of students to fulfill the needs of Scientific Information, through the valence (value) of information and quality of information. Based on the results of path analysis, valence (value) of information and quality of information, both influence directly or indirectly to quality of information, it is the most influential variable on student attitudes as well as prior knowledge has a significant effect on the valence and quality information.

Key words : valence of information, value of information, quality of information, website, internet, attitude.

\section{PENDAHULUAN}

Perkembangan teknologi komunikasi dan informasi terjadi begitu pesatsehingga ditempatkan dalam posisi strategis di suatu instansi atau lembaga.Teknologi komunikasi dan informasi ini dapat mempercepat akselerasi 
penyebaran informasi dan memperoleh informasi untuk memenuhi kebutuhan dalam kehidupan sehari-hari.Perkembangan ini harus disikapi sebagai peluang dan tantangan yang perlu diantisipasi dengan jalan menyiapkan perangkat dan sistem jaringan teknologi komunikasi dan informasi yang dapat dengan mudah diakses dan dimanfaatkan oleh pengguna.

Penggunaan teknologi komunikasi dan informasi di bidang perpustakaan telah mempopulerkan istilah e-book, e-journal, $e$ article, dan e-library.Istilah-istilah tersebut merupakan alih bentuk informasi secara fisik menjadi elektronik hasil dari kecanggihan teknologi komunikasi dan informasi. Selain itu dalam menyebarluaskan informasi terkait dengan seluruh koleksi dan layanan yang ada di perpustakaan perguruan tinggi, saat ini mengalami perubahan ke dalam bentuk digital, dengan menggunakan media komputer menjadi $e$ brosur, e-leaflet, dan lainnya. Kemajuan teknologi informasi dan komunikasi ini telah menawarkan berbagai alternatif saluran media komunikasi dan informasi. Salah satu nya yaitu internet.

Komunikasi melalui internet layaknya komunikasi dengan menggunakan media lainnya. Internet berperan sebagai saluran (channel) untuk menyampaikan pesan (message) dari komunikator atau sumber pesan (source) kepada komunikan atau penerima pesan (receiver). Pesan (message) di sini berupa kumpulan informasi-informasi yang dapat diakses oleh pengguna perpustakaan. Keberadaan internet sebagai media komunikasi atau sebagai salah satu media pencarian informasi yang memudahkan penggunanya dalam mengakses atau mentransfer informasi, sehingga sangat memungkinan terciptanya pencarian informasi yang efektif. Kebutuhan informasi yang semakin tinggi terlebih di lingkungan pendidikan, menjadikan internet sebagai salah satu fasilitator atau media komunikasi yang sangat dibutuhkan dan sudah menjadi kebutuhan primer dalam pemenuhan kebutuhan informasi dikalangan mahasiswa.

Perpustakaan Universitas Bina Nusantara berada di lingkungan masyarakat melek teknologi, dituntut untuk selalu berkembang selaras dengan perkembangan teknologi. Mahasiswa sebagai aktor utama masyarakat perguruan tinggi dan juga sebagai pengguna aktif perpustakaan, merupakan pengguna potensial dari teknologi informasi dan komunikasi. Berdasarkan survei yang telah dilakukan oleh APJII (Asosiasi Penyelenggara Jasa Internet Indonesia) Desember Tahun 2012, pengguna internet di Indonesia berdasarkan Usia; 12-34 Tahun $(64,2 \%)$ dan 20-24 Tahun $(15,1 \%)$. Jumlah pengguna internet berdasarkan usia 12-34 Tahun mendominasi pengguna internet $\mathrm{di}$ Indonesia. Sedangkankanusia 12-34 Tahun merupakan usia peserta didik, termasuk mahasiswa. Berdasarkan Peraturan Pemerintah RI No.30 tahun 1990, mahasiswa adalah peserta didik yang terdaftar dan belajar di Perguruan tinggi.Mahasiswa merupakan pelajar yang menimba ilmu di perguruan tinggi yang memiliki kematangan fisik dan pemikiran dan bertanggung jawab terhadap sikap dan perilaku dalam wacana ilmiah.

Mahasiswa sebagai pengguna potensial perpustakaan jelas sangat membutuhkan informasi ilmiah dalam mendukung kegiatan belajar. Informasi ilmiah bersumber pada buku, jurnal, hasil penelitian, dan karya ilmiah lainnya (skrips, tesis, disertasi).Sumber-sumber informasi tersebut harus dapat diakses secara cepat dan mudah.

Saat ini seluruh layanan dan penyebaran informasi perpustakaan Universitas Bina Nusantara dapat diakses melalui website menggunakan jaringan internet.Sehingga seluruh civitas akademika dapat mengakses beragam informasi dari berbagai tempat dengan mudah dan cepat. Hal ini sesuai dengan sifat internet, dimana pengguna akan mendapatkan informasi secara real time, interaktif, dan menyediakan berbagai alat untuk presentasi ringkas dan pengorganisasian informasi. Dalam perkembangannya saat ini, website juga memiliki sifat komunikasi massa dimana memiliki modelbottom-up,desentralisasi, berjaringan, dan interaktif. Artinya informasi yang dipublikasikan melalui website dapat langsung diterima secara menyeluruh oleh masyarakat dalam hal ini mahasiswa Universitas Bina Nusantara.

Website perpustakaan Universitas Bina Nusantara telah mengadopsi website generasi 2.0 atau disebut website 2.0. Website generasi ke-2 muncul pada awal tahun 2004 bertujuan supaya pengguna dapat berinteraksi langsung dengan penyedia informasi. Website 2.0 juga disebut website partisipatoris, dimana pengguna website dapat berpartisipasi secara langsung dalam penciptaan dan penyebaran pengetahuan. Partisipasi mahasiswa Universitas Bina Nusantara 
melalui website perpustakaan dapat berupa usulan berbagai referensi sebagai pendukung belajar, memberikan saran dan kritik mengenai seluruh aktivitas perpustakaan, ulasan atau komentar mengenai referensi.Melalui media website layanan perpustakaan tidak lagi hanya sebatas interaksi peminjaman dan pengembalian buku namun mahasiswa juga dapat lebih peduli, kritis, dan aktif.Perubahan sikap tersebut dipengaruhi oleh lingkungan perpustakaan yang telah mengadopsi teknologi sebagai media dalam berinteraksi.Hal ini merujuk pada aliran behaviorisme bahwa perilaku dalam hal ini sikap dikendalikan oleh faktor-faktor lingkungan. (Syam, Nina W. 2011: 76). Selain itu, partisipasi pengguna melalui website 2.0 merupakan reaksi dari pengguna sebagai pengguna yang cermat terhadap stimulus yang diberikan oleh perpustakaan melalui website 2.0.

Partisipasi penggunaan website perpustakaan merupakan respon terhadap stimulus yang ada pada website melalui penyediaan beragam fitur yang interaktif dan informatif. Seperti yang dikatakan Hovland, Janis, dan Keley (1953) "perubahan sikap tergantung pada kualitas stimulus yang berkomunikasi dengan organism". (Hovland, Janis, dan Keley (1953) dalam Mar'at. 1984, 6).Dalam hal ini fitur-fitur dan kelengkapan informasi pada website perpustakaan telah memberikan stimulus pada mahasiswa sehingga menggunakan website secara maksimal.

Website Perpustakaan Universitas Bina Nusantara dengan alamat situs http://library.binus.ac.id telah diakses sebanyak 124.864 kali $^{1}$ melalui $\log$ in dengan menggunakan user id (nomor pokok mahasiswa, nomor induk pegawai, nomor kode dosen), artinya bahwa informasi yang terdapat dalam website telah dimanfaatkan oleh seluruh civitas akademika Universitas Bina Nusantara.

Penggunaan website 2.0 di Perpustakaan Universitas Bina Nusantara tidak terlepas dari faktor informasi sebagai suatu unsur penting dan mendapatkan perhatian mahasiswa. Karena informasi yang tersedia dalam website memiliki korelasional dengan pemenuhan kebutuhan informasi ilmiah untuk menunjang kegiatan belajar mahasiswa. Infomasi yang sesuai dengan kebutuhan cenderung akan selalu digunakan oleh mahasiswa. Informasi yang sesuai kebutuhan mahasiswa harus memiliki bobot setidaknya memiliki keakuratan, ketepatan dan relevan. Senada dengan pendapat Burch, bahwa bobot informasi dibagi menjadi tiga bagian yaitu informasi harus akurat (accurate), tepat pada waktunya (timeliness) dan relevan (relevance) (Burch 1986, 5). Sedangkan menurut Mc. Leod (1997) mengemukakan bahwa suatu informasi yang berkualitas memiliki ciri: akurat, tepat waktu, relevan, dan lengkap (Rusman 2011, 33).Selain itu juga informasi harus dapat mendukung kepercayaan penggunanya dalam hal ini mahasiswa.Ketika informasi mendukung keyakinan seseorang, maka informasi tersebut mempunyai valensi positif, sedangkan jika informasi tidak mendukung keyakinan seseorang, maka informasi tersebut memiliki valensi negatif. Informasi dalam suatu media memiliki kekuatan potensial yang dapat mempengaruhi orang untuk memiliki sikap tertentu. Dalam hal ini informasi yang terdapat dalam website memiliki pengaruh dalam sikap mahasiswa sebagai pengguna informasi tersebut. (Feishbein dalam Little John2011, 111-114)

Website Perpustakaan Universitas Bina Nusantara telah dikembangkan sejak tahun 2006 mengadopsi fitur-fitur website 2.0, menampilkan beragam informasi yang dapat diakses oleh mahasiswa Universitas Bina Nusantara seperti informasi kelembagan, informasi ilmiah, informasi interaktif, dan informasi lainnya. Penggunaan informasi melalui website perpustakaan Universitas Bina Nusantara tidak terlepas dari pengetahuan terdahulu (prior knowledge) para pengguna yaitu mahasiswa.Prior knowledge adalah segala pengetahuan yang telah dimiliki dan telah siap digunakan oleh seseorang (Sumarto, Hadi, 2013: 19). Pengetahuan terdahulu meliputi semua pengalaman tentang suatu informasi atau ide, persepsi, dan konsep serta imaji yang terdapat dalam otak seseorang.

Penyediaan informasi melalui website dengan segala kemudahannya diiharapkan dapat memenui kebutuhan informasi ilmiah mahasiswa serta berpengaruh pada sikap mahasiswa dalam memenuhi kebutuhan informasi ilmiahnya dilihat dari komponen kognisi, afeksi, dan konasi.

Akan tetapi sudahkah informasi website tersebut digunakan secara maksimal oleh mahasiswa dan mengubah sikap mahasiswa dalam memenuhi kebutuhan informasinya?Untuk itu penulis akan melakukan penelitian dengan judul 
"Pengaruh Informasi Website Perpustakaan Terhadap Sikap Mahasiswa Dalam Memenuhi Kebutuhan Informasi Ilmiah.”

\section{Tujuan Penelitian}

Penelitian ini bertujuan untuk:

1. Mengetahui dan menganalisis pengaruh pengetahuan terdahulu terhadap valensi informasi website Perpustakaan Universitas Bina Nusantara.

2. Mengetahui dan menganalisis pengaruh pengetahuan terdahulu terhadap bobot informasi website Perpustakaan Universitas Bina Nusantara.

3. Mengetahui dan menganalisis pengaruh valensi informasi website Perpustakaan Universitas Bina Nusantara terhadap sikap mahasiswa dalam memenuhi kebutuhan informasi ilmiah.

4. Mengetahui dan menganalisis pengaruh bobot informasi website Perpustakaan Universitas Bina Nusantara terhadap sikap mahasiswa dalam memenuhi kebutuhan informasi ilmiah.

5. Mengetahui dan menganalisispengaruh informasi website perpustakaan terhadap sikap mahasiswa dalam memenuhi kebutuhan informasi ilmiah.

\section{METODE PENELITIAN}

Metode penelitian yang digunakan dalam penelitian ini adalah pendekatan surveyexplanatory. Menurut Rusidi (1992, 24) pendekatanexplanatory merupakan "metode penelitian yang bertujuan untuk menguji hipotesis dengan cara mendasarkan pada pengamatan terhadap akibat yang terjadi dan mencari faktorfaktor yang mungkin menjadi penyebabnya melalui data tertentu". Selain itu, ciri berikutnya dari pendekatan explanatory adalah informasi dikumpulkan dan diambil dari sampel atas populasi, dengan menggunakan kuisioner sebagai alat pengumpulan datanya.

Pengumpulan data dalam penelitian ini menggunakan metode survei, mengingat data yang dikumpulkan sebagian besar adalah data yang diperoleh dari lapangan (data primer). Data primer diperoleh berdasarkan wawancara dan hasil jawaban para mahasiswa terhadap pertanyaan-pertanyaan yang diajukan dalam kusioner. Selain data primer dilakukan studi pustaka dan literatur lainnya yang berhubungan dengan masalah yang sedang diteliti.
Variabel bebas/independen (X) dalam penelitian ini adalah Penggunaan Informasi Website, $\quad \mathbf{x}_{\mathbf{1}}$ Valensi, $\quad \mathbf{x}_{2}$ Bobot Penilaian. Sedangkan variabel terikat/dependen (Y) adalah Sikap Mahasiswa Dalam Memenuhi Kebutuhan Informasi Ilmiah., dan Variabel A (antiseden) yaitu Pengetahuan Terdahulu.

\section{Populasi dan Sampel}

Populasi penelitian ini adalah pengguna website perpustakaan yaitu mahasiswa sebagai pengguna perpustakaan yang telah melakukan login terlebih dahulu. Ukuran populasi dalam penelitian ini berjumlah 1371 orang. Untuk menentukan sampel penulis menggunakan rumus Yamane untuk menentukan ukuran sampel dengan presisi 5\%. Dari populasi 1371orang, diperoleh ukuran sampel sebanyak 310 orang mahasiswa yang akan dijadikan responden dalam penelitian ini.

\section{Teknik Pengumpul Data}

Dalam penelitian yang dilakukan digunakan beberapa teknik untuk mendapatkan data yang selengkap-lengkapnya untuk penunjang penetilian ini, antara lain : angket, wawancara, dan kepustakaan.

Dalam teknik pengumpulan data dengan menggunakan angket sebelumnya dilakukan uji validitas dan reliabilitas. Untuk uji validitas menggunakanrumus korelasi product moment atau dikenal juga dengan korelasi pearson.

Adapun cara untuk menganalisis adalah dengan mengkorelasikan masing-masing skor item dengan skor total dan mengoreksi nilai koefisien korelasi yang overestimasi. Dari hasil penghitungan akan diperoleh nilai korelasi antara skor item dengan skor total $\left(\mathrm{r}_{\text {hitung }}\right)$ yang dapat digunakan untuk menguji validitas instrumen.Setelah dilakukan perhitungan diperoleh hasil yang menunjukkan bahwa nilai korelasi (r) untuk skor item dengan total skor variabel $\mathrm{X}$ dan $\mathrm{Y}$, rata-rata jauh diatas 0,3 , maka semua dapat diketahui bahwa item-item tersebut valid dan untuk itu kuesioner yang digunakan layak untuk diolah sebagai data penelitian. Instrumen dikatakan reliabel, jika koefisien korelasi hasil perhitungan mempunyai nilai lebih besar atau $=0,7$ (angka kritis). 


\section{Teknis Analisis Data dan Uji Hipotesis Teknik Analisis Data}

Metode analisis data yang digunakan adalah metode kualitatif dan metode kuantitatif, dimana : Metode kualitatif dilakukan untuk mengemukakan data yang masuk dengan cara mengelompokan data, mentabulasikannya dan kemudian diberi penjelasan

Untuk memperkuat analisis kualitatif diatas, diperlukan analisis kuantitatif/inferensial, yaitu analisis untuk menguji hipotesis atau mengetahui besarnya pengaruh kualitas informasi baik secara simultan maupun parsial, langsung dan tidak langsung, yang terdiri dari ketepatan, timeliness, akurasi, berkurang ketidakpastian dan unsur kejutan terhadap kepuasan Dosen menggunakan analisis jalur (path analysis)

\section{Uji Hipotesis}

(i) Pengujian Koefisien Jalur Secara Bersamasama.

H0 : Semua $\rho Y X i=0$ Tidak terdapat pengaruh pengetahuan $\mathrm{i}=1,2$

terdahulusecara bersama-sama terhadap valensi dan bobot informasi yaitu valensi (X1), bobot informasi (X2), atau disebut juga sebagai variabel endogen, serta variabel dependen yaitu sikap mahasiswa (Y) disebut sebagai variabel eksogen, serta variabel antesedent yaitu pengetahuan terdahulu (A) sehingga penelitian ini akan dikembangkan menjadi model penelitian seperti gambar pada struktur jalur penelitian, sebagai berikut:

Gambar 1

\section{Struktur Jalur Variabel Penelitian}

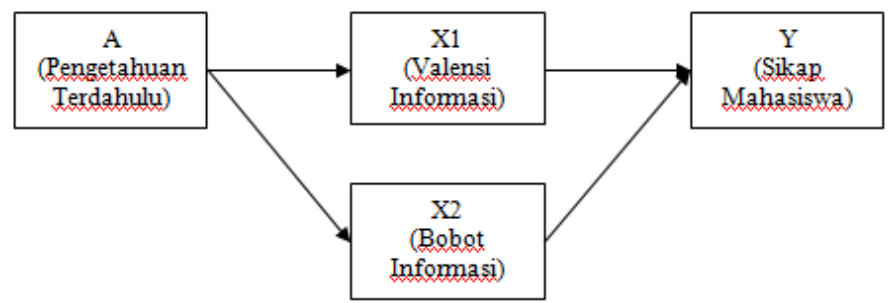

Sumber : Juanim, 2004 : 19 (dioleh oleh penulis) Keterangan :

$\mathrm{A}=$ Pengetahuan terdahulu

$\mathrm{X}_{1}=$ Valensi

$\mathrm{X}_{2}=$ Bobot Informasi

$\mathrm{Y}=$ SikapMahasiswa

H1 : Ada $\mathrm{YXi} \neq 0$ Terdapat pengaruh pengetahuan $\mathrm{i}=1,2,3$ terdahulu secara bersama-sama terhadap valensi dan bobot informasi informasi website perpustakaan terhadap sikap mahasiswa Universitas Bina Nusantara, yang akan

H0 : Semua $\rho Y X i=0$ Tidak terdapat pengaruh valensi dan $\mathrm{i}=1,2 \quad$ bobot informasi secara bersama-sama terhadap sikap mahasiswa

diukur melalui variabel pengetahuan terdahulu yang berpengruh terhadap valensi (nilai) dan bobot informasi serta mengukur variabel valensi

H0 : Semua $\rho$ Yxi $\neq 0$ Terdapat pengaruh valensi dan bobot (nilai) dan bobo informasi terhadap sikap $\mathrm{i}=1,2 \quad$ informasi secara bersama-sama terhadap sikap mahasiswa

(ii) Pengujian Koefisien Jalur Secara Individual.

$\mathrm{H} 0: \rho \mathrm{YXi}=0 \quad$ Tidak terdapat pengaruh pengetahuan $\mathrm{i}=1$

terdahulusecara parsial terhadap valensi (nilai) dan bobot informasi.

$\mathrm{H} 1: \rho \mathrm{YXi} \neq 0 \quad$ Terdapat pengaruh pengetahuan $\mathrm{i}=1 \quad$ terdahulusecara parsial terhadap valrensi (nilai) dan bobot informasi.

$\mathrm{H}_{0}: \rho_{\mathrm{YXi}}=0 \quad$ Tidak terdapat pengaruh valensi dan $\mathrm{i}=1,2$ bobot informasi website secara parsial $\mathrm{H}_{1}: \rho_{\mathrm{YXi}} \neq 0$ $\mathrm{i}=1,2$ terhadap sikap mahasiswa.

Terdapat pengaruh valensi dan bobot informasi website secara parsial terhadap sikap mahasiswa.

Statistik uji yang digunakan pada pengujian secara individual masing-masing subvariabel adalah statistik uji-t

Dalam penelitian ini menggunakan analisis jalur dengan 2 (dua) variabel independen, mahasiswa dalam memenuhi kebutuhan informasi ilmiah.

\section{HASIL PENELITIAN \\ a. Analisis Jalur}

Untuk melihat pengaruh pengetahuan terdahulu berpengaruh terhadap valensi (nilai) dan bobot informasi maupun pengaruh valensi (nilai) dan bobot informasi terhadap sikap mahasiswa dalam penelitian ini digunakan path analysis.Perhitungan Analisi jalur mensyaratkan data yang digunakan memiliki skala pengukuran interval. Untuk memenuhi syarat data hasil penyebaran kuesioner dan mempunyai skala pengukuran ordinal, terlebih dahulu ditransformasikan menjadi skala interval melalui MSI.

Diperoleh koefisien jalur dari pengetahuan terdahulu terhadap valensi (nilai) informasi sebesar 0,504 dan koefisien jalur dari 
pengetahuna terdahulu terhadap bobot informasi sebesar 0,654. Persamaan koefisien jalur yang terbentuk dalam menjelaskan pengaruh pengetahuan terdahulu terhadap valensi dan bobot informasi dapat dinyatakan sebagai berikut :

$$
X=0,504 A+0,654 A+\varepsilon
$$

Sedangkan koefisien jalur dari valensi (nilai) informasi website terhadap sikap mahasiswa $\left(\mathrm{P}_{\mathrm{YX} 1}\right)$ sebesar 0,071 dankoefisien jalur dari bobot informasi website terhadap sikap mahasiwa $\left(\mathrm{P}_{\mathrm{YX} 2}\right)$ sebesar 0,688. Persamaan koefisien jalur yang terbentuk dalam menjelaskan

\begin{tabular}{|c|c|l|c|c|c|}
\hline $\begin{array}{c}\text { Hipotesis } \\
\text { Alternatif }\end{array}$ & $\begin{array}{c}\mathbf{F} \\
\text { hitung }\end{array}$ & \multicolumn{1}{|c|}{$\mathbf{d b}$} & $\begin{array}{c}\mathbf{F} \\
\text { tabel }\end{array}$ & Sig & Kesimpulan \\
\hline$X_{1}$ dan & & $\mathrm{db}_{1}=2$ & & & \\
$X_{2}$ secara & 184.126 & $\mathrm{db}_{2}=$ & 2,65 & 0,00 & $\begin{array}{c}\text { Ho ditolak } \\
\text { (Signifikan) }\end{array}$ \\
$\begin{array}{c}\text { simultan } \\
\text { berpengaruh } \\
\text { terhadap Y }\end{array}$ & & 307 & & & \\
\hline
\end{tabular}

pengaruh valensi dan bobot informasiterhadap sikap mahasiswa dapat dinyatakan sebagai berikut

$$
\mathrm{Y}=0,071 \mathrm{X}_{1}+0,688 \mathrm{X}_{2}+0,455
$$

Model struktural pengaruh valensi (nilai) informasi dan bobot informasi terhadap sikap mahasiswa dapat digambarkan sebagai berikut :

\section{Gambar 2}

\section{Model Struktural Pengaruh X terhadap Y}

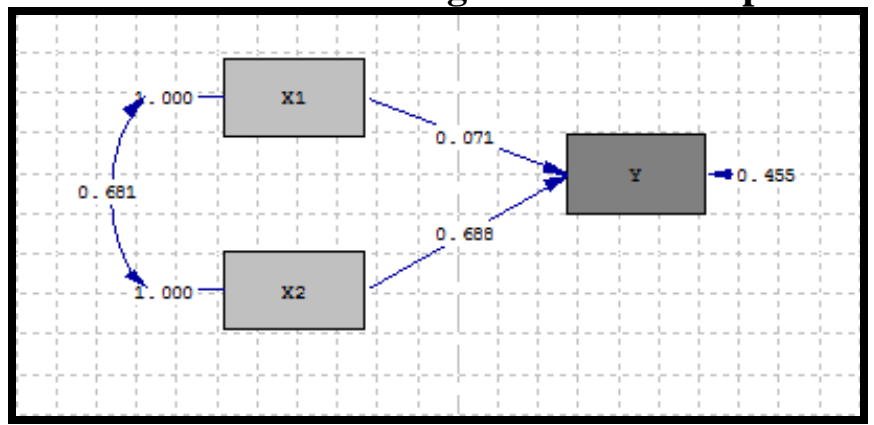

b.Pengujian Hipotesis

Sebelum memberikan interpretasi lebih jauh secara umum dalam populasi mengenai pengaruh variabel yang diteliti terlebih dilakukan pengujian apakah pengetahuan terdahulu (A) berpengeruh terhadap Valensi (nilai) informasi $\left(\mathrm{X}_{1}\right)$ dan Bobot Informasi maka didapat hasil sebagai berikut:

- Nilai t hitung lebih besar dari t tabel yaitu 10,228 > 1,65, maka Ho ditolak. Artinya bahwa pengetahuan terdahulu berpengaruh terhadap valensi informasi.

- Nilai t hitung lebih besar dari t tabel yaitu 15,180 > 1,65, maka Ho ditolak. Artinya bahwa pengetahuan terdahulu berpengaruh terhadap bobot informasi.

Sedangkan pengujian apakah (nilai) informasi $\left(\mathrm{X}_{1}\right)$ dan Bobot Informasi $\left(\mathrm{X}_{2}\right)$ berpengaruh terhadap Sikap Mahasiswa (Y). Pengujian hipotesis dilakukan melalui dua tahap yaitu pengujian pengaruh secara simultan dan pengujian pengaruh secara parsial.

- Pengujian Koefisien Jalur Secara Simultan

Nilai $F$ hitung diperoleh dengan perhitungan sebagai berikut :

$$
F=\frac{(n-k-1) R_{y x 1 x 2 \ldots x k}^{2}}{k\left(1-R^{2}{ }_{y x 1 x 2 \ldots x k}\right)}
$$

Kriteria uji: Tolak Ho jika F hitung $\geq F$ tabel, terima Ho dalam hal lainnya. Dimana $F$ tabel diperoleh dari tabel distribusi $\mathrm{F}$ dengan $\alpha=5 \%$ dan derajat bebas $\mathrm{db}_{1}=\mathrm{k}$, dan $\mathrm{db}_{2}=\mathrm{n}-\mathrm{k}-1$

\section{TABEL 1}

\section{Pengujian Secara Simultan}

Pada tabel di atas dapat kita ketahui bahwa hasil pengujian signifikan yang berarti valensi dan bobot informasi secara simultan memiliki pengaruh yang signifikan terhadap sikap mahasiswa.

\section{- Pengujian Koefisien Jalur Secara Parsial}

Setelah prosedur pengujian simultan $\mathrm{H}_{0}$ ditolak, dan disimpulkan terdapat pengaruh secara bersama-sama, selanjutnya dilakukan pengujian parsial. Statistik uji yang digunakan adalah uji $\mathrm{t}$ dimana $t_{\text {hitung }}$ diperoleh hasil perhitungan sebagai berikut:

\section{Tabel 2}

\section{Uji Hipotesis Pengaruh secara Parsial}

\begin{tabular}{|c|c|c|c|c|l|c|}
\hline No & Hipotesis & $\begin{array}{c}\text { Koefisien } \\
\text { Jalur }\end{array}$ & $\begin{array}{c}\mathbf{t} \\
\text { hitung }\end{array}$ & $\begin{array}{c}\mathbf{t} \\
\text { tabel }\end{array}$ & Keputusan & Kesimpulan \\
\hline 1 & $P_{y x 1}=0$ & 0.071 & 1.359 & 1,65 & $\mathrm{H}_{0}$ diterima & $\begin{array}{c}\text { Tidak } \\
\text { Signifikan }\end{array}$ \\
\hline 2 & $P_{y x 2}=0$ & 0.688 & 13.091 & 1,65 & $\mathrm{H}_{0}$ ditolak & Signifikan \\
\hline
\end{tabular}

\section{c. Besar Pengaruh}

Dari hasil pengujian hipotesis diperoleh kesimpulan terdapat pengaruh yang signifikan (nyata) secara bersama-sama dan secara parsial dari valensi (nilai) informasi dan bobot informasi terhadap sikap mahasiswa. Total pengaruh yang diperoleh sebesar $54.6 \%$ dan pengaruh faktor lain di luar kedua faktor tersebut adalah sebesar $45.4 \%$. 


\section{SIMPULAN}

Dimensi informasi website perpustakaan Universitas Bina Nusantara ini meliputi valensi (nilai) informasi dan bobot informasi, secara umum berpengaruh terhadap sikap mahasiswa dalam memenuhi kebutuhan informasi ilmiahnya.

Dari penelitian ini sikap mahasiswa Universitas Bina Nusantara merasa terpenuhi kebutuhan informasi ilmiahnya dengan mengakses website perpustakaan terutama karena informasi website perpustakaan memiliki bobot informasi seperti relevan, akurat, tepat waktu, dan lengkap.

\section{DAFTAR PUSTAKA}

APJII (Asosiasi Penyelenggaraan Jasa Internet Indonesia). Melalui 〈www.apjii.or.id> [05/09/13], pukul 19.30 wib.

Littlejohn, Stephen W. and Karen A. Foss. 2011. Teori Komunikasi Theoris of Human Communications. Edisi 9. Jakarta: Salemba Humanika.

Mar'at. 1984. Sikap Manusia perubahan Serta Pengukurannya. Jakarta: Ghalia Indonesia.

Rusman. 2011. Pembelajaran Berbasis Teknologi Informasi dan Komunikasi. Jakarta: Raja Grafindo Persada.

Sanjaya, W. 2009. Strategi Pembelajaran Berorientasi Standar Proses Pendidikan. Jakarta: Kencana.

Syam, Nina W. 2011. Psikologi sebagai Akar Ilmu Komunikasi. Bandung: Simbiosa Rekatama Media. 